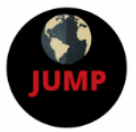

ISSN: 2574-3465 Print/ ISSN: 2574-3481 Online

Volume 1, Issue 1 (2017), pp. 3-7

(C) Journal of Underrepresented and Minority Progress

$\mathrm{http} / / /$ minorityprogress.org/

doi: $10.5281 /$ zenodo. 1165450

\title{
Framing Culture and Diversity Today: Cultural Hegemony
}

\author{
Benjamin H. Welsh \\ Morgan State University, United States
}

\begin{abstract}
The theoretical essay uses Antonio Gramsci's theory of cultural hegemony to examine the rise of Trump. The first in a series, it initiates the argument that cultural hegemony must be taken into account when discussing issues related to culture and diversity, beginning with class or socioeconomic status differences.
\end{abstract}

When I first entered the field of education in the 1980's, multicultural education and critical pedagogy were treated as separate areas of study. Multicultural education emphasized curriculum enrichment, where the K-12 curriculum was supposed to be infused with information about different racial and ethnic minority groups that had previously been left out. In the beginning, multicultural education was essentially a repackaging of ethnic studies for the public schools, albeit with less of a Euro-centric orientation. In contrast, critical pedagogy emphasized classroom activism and student empowerment around economic injustice. An application of critical theory to education that began with Paulo Freire (1970/2000), critical pedagogy sought to move teachers and students to an awareness of how capitalism created a stratified society, and how formal education contributed to the reproduction of that stratification.

As a doctoral student in a social justice program the 1990's, I saw an immediate need to bring multicultural education and critical pedagogy together. In my mind, at least, information about racial and ethnic groups was of little benefit unless discussions of the socio-economic and political contexts were also included. Similarly, when examining the impact of capitalism on education, it was clear to me that discrimination along racial, ethnic, and even gender lines was almost always part of the equation. Thankfully, I was not alone. On the multicultural education side, James Banks (1993) made a strong case for moving beyond curriculum or content to include pedagogy that was more culturally sensitive and aimed at raising student consciousness. And, on the critical pedagogy side, Joe Kincheloe (1993) was quite candid in his discussion of capitalism, recognizing that racism had always gone hand-in-hand with capitalism when it comes to formal education and society. Indeed, encountering these authors made me feel as though I had finally met my intellectual 'birth parents'. And, like any young child of unmarried parents, I did everything I could to bring them together.

Unfortunately, from my point of view, at least, multicultural education and critical pedagogy never officially tied the knot. Instead, they have had something resembling a long-term relationship punctuated by occasional one-night stands. These one-night stands have given birth to different offspring with distinctively different personalities and agendas - so different that they rarely talk to one another anymore. The offspring include critical race theory, culturally relevant 
pedagogy, and critical white studies. While multicultural education and critical pedagogy may now be too old to get married, it is not too late to call for a family reunion. And, it is in the spirit of such a family reunion that this essay was undertaken. But, in the light of our reluctant entry into the Age of Trump, the purpose of the family reunion being called for has undergone something of a transformation. Originally, its purpose was to call for a common theoretical framework for all future discussion of culture and diversity that acknowledged dimensions of power and dominance. But, in the light of the Trump election, its purpose has become something more of call to action. In the Age of Trump, if we academics continue to operate in isolated silos without joining together intellectually, professionally, and personally, and we do so at our peril! It should now be completely clear exactly how fragile civilization is. In the space of a few years, Gramsci's fate could easily become our own.

What follows is the first installment of a three-part paper: the political context, the cultural context, and the role of education.

Early in 2010, following the Democrats' loss of their supermajority in the Senate, the BBC published a story that caught my eye. Entitled, Why do people vote against their own interest (BBC, 2010)? the story jumped out at me because it purported to explore the reasons why people voted against policies that they themselves would benefit from. The example at the center of the article was Obama's healthcare reform bill, which would be known as the Affordable Care Act or Obamacare, and which was still a few months away from being signed into law.

A description of the paradox began the article. It pointed out that the voters who were the most openly hostile to healthcare reform happened to belong to the very same group that the bill was intended to help - namely the working poor who were underinsured or not insured. A summary of author Thomas Frank's explanation of the paradox ended the article. Frank attributed it to a kind of manufactured class struggle, where the Republican party had conditioned the working poor to view the Democratic party as a "patronizing [sic.] liberal elite" $(B B C$, Reverse Revolution section, para. 3) that was telling it what to think and do. The article ended with the following statement: "The result is that many of America's poorest citizens have a deep emotional attachment to a party that serves the interests of the richest" ( $B B C$, Reverse Revolution section, para. 11). This was written six years before the election of Donald Trump.

Circa 2010, when I first encountered the BBC article, I remained politically naïve, in spite of having been grounded in Weber's political theory of authority as an undergraduate. In truth, I was so naive that I could not get past the article's title. How could anyone under any circumstance vote against their own interest? As a rank and file democrat living in a consistently blue state, the idea was completely alien to me. Over time, however, as I reflected on my own political bias, my incredulity softened. And, with the election of Donald Trump, I had no choice but to accept 'voting against self-interest' as an incontrovertible fact. And, whether intended or not, the exploitation of this propensity among poor rural Americans seems goes back at least as far as Newt Gingrich's Contract with America in 1994.

We should be alarmed (but not surprised) that Antonio Gramsci (1891-1937), Marxist, journalist, politician, and political philosopher, bore witness to a similar political movement in Italy in the early decades of the $20^{\text {th }}$ century. Gramsci was active in Socialist and Communist circles circa 1912, at the same time as Benito Mussolini. Then, after Mussolini rejected socialism, embraced nationalism and strong-armed his way into power in 1922, Gramsci witnessed Italy collapse into a one-party fascist dictatorship almost overnight. In five years or less, Mussolini dismantled liberal Italy by re-writing the Constitution, undermining the opposition parties, and closing democratic institutions. Then, in 1926, Mussolini imprisoned Gramsci under false 
pretense. Eleven years later, at the age of 46, Gramsci died from illnesses complicated by his imprisonment. While in prison, Gramsci produced writings that remain relevant today. In them, he critiqued Marxism, capitalism and fascism, among many other topics in over 3000 pageswritings that became known as his Prison Notebooks (Gramsci, 1971/1999).

As one might expect from an early $20^{\text {th }}$ century Marxist, Gramsci $(1971 / 1999)$ explored the relationships between socio-economic groups in his notebooks. But, what made Gramsci's contribution unique, when compared with Marx, was his position in history. Not only had Gramsci been an active part of a political revolution similar to that which had been anticipated by Marx's theory, he had witnessed the revolution's demise in the face of World War I. Instead of leading to a utopia in which members of all classes were freed from the bondage of capitalism, as Marx had predicted, the revolution had led to a violent crackdown by an openly fascist, nationalistic dictatorship that was far more repressive than the social-democratic government it had replaced. In short, from Gramsci's vantage point, at least, recent history had shown Marx's theory to be wrong. Exactly where it went wrong appears to be at the heart of Gramsci's notebooks. And, his answer is most evident in his concept of hegemony (Bates, 1975).

In classic Marxist theory, capitalist societies were seen as arranging themselves into economically-based social strata. In the drive to make money and control the means of production, the upper strata exploited and oppressed the lower strata until the lower strata revolted against the upper strata. And, such revolutions were supposed to continue until capitalism and stratifications both disappeared, or so the theory went. The social stratification, together with the socio-economic mechanisms that maintained it, could be characterized as 'hegemony', given the most basic definition of the term (Bates, 1975).

But, Gramsci (1971/1999) recognized that there was more to hegemony than met the eye (Bates, 1975). To fully understand how the upper classes maintained control of the lower classes and exploited them, one had to take into account the belief system or ideology of the subordinate group. This learned, internalized side of hegemony Gramsci termed 'cultural hegemony'. And, since the ideology of the lower classes could be manipulated by the upper classes to serve the upper classes, revolutions, such as those foretold by Marx, were not inevitable. Instead, Gramsci's understanding of cultural hegemony suggested that the lower classes could become willing participants in their own subjugation, depending on their belief system and especially the views that they accepted as 'common sense'. The result could be willing participation in Mussolini's brutal dictatorship, or, in the present day, open hostility for Obamacare and the election of Donald Trump.

As convenient as it would be for me to paint Trump as 'bad fascist dictator' and Hillary as 'good social democrat', the 2016 election was not that simple. Indeed, we must remember that Trump's rise to power, unlike Mussolini's, was not a one-sided affair. Where Mussolini was swept into power as part of a coup d'état that either subsumed the opposition through intimidation or destroyed it through violence, Trump was elected peacefully, in accordance with the law. Thus, understanding how Hillary and the Democrats lost the election became just as important as understanding how Trump and Republicans won it. Gramsci's concept of cultural hegemony can help us do both.

One of the key elements of cultural hegemony is social stratification (Gramsci, 1971/1999) --at least one upper and one lower class. And, in the case of the 2016 election, class differences were undoubtedly at play. The winning side was marked by Trump's core supporters, the working poor, rural, un-college educated white Americans--the same group focused on in the $\mathrm{BBC}$ article discussed above. In contrast, the losing side was marked by the Democratic 'rank 
and file' represented by the middle-class, urban, college educated white Americans of which I am one.

Another key element of cultural hegemony is an ideology (Gramsci, 1971/1999) based on faulty beliefs. These beliefs are faulty because they do not benefit the strata that holds the beliefs (and may actually harm it, as in the case of the disdain for Obamacare discussed above). They are also faulty because they are essentialized or overly simplistic, on one hand, and accepted by the believers as obvious or common sense, on the other. Finally, to make a belief an instance of cultural hegemony, the upper strata must benefit from the belief, politically, economically, or both. Thus, the anti-Obamacare example becomes cultural hegemony only if the insurance companies (or other wealthy entity) benefits financially from its rejection at the expense of those who rejected it.

My experience suggests that the beliefs that make up cultural hegemony are often (but not always) indicated by pithy expressions that conceal the complexity of an issue. Examples include: "freedom isn't free," "guns don't kill people, people kill people," "abortion is murder," and "buy American" (or, in its Bush-era configuration, "Support America. Go Shopping.") My assertion is that these expressions indicate the presence of cultural hegemony. But, while the Right-wing is frequently associated with these expressions, among others, we must avoid thinking that the Left is somehow exempt from an ideology that is similarly faulty, and which would lead to cultural hegemony. Indeed, both criteria are met: there is a stratum above the disproportionately college-educated, middle class, Left that would benefit from cultural hegemony. And, there is evidence of a faulty ideology among the Left that would serve the upper strata.

I daresay that one of the biggest signs that faulty beliefs are at play with the Democrats is found with Hillary Clinton's loss and the subsequent shock felt by her and many of her supporters. After all, had Hillary and the Democrats fully grasped the degree of their opponents' political zeal, they would have done things differently. And, had they done things differently, they might have won. Or, if they had lost in spite of understanding their opponent, they would not have been as completely shocked and dumbfounded by the loss as they were. In other words, a faulty ideology appears to have blinded Hillary and her supporters from seeing the truth about America's electorate. Thus, the beliefs were flawed, suggesting the presence of cultural hegemony on Democratic side of the aisle. While the Democrats may share some faulty beliefs with the Republicans (such as "Support America. Go Shopping" and others), what is perhaps more relevant to the discussion of the 2016 election are those beliefs that appeared to be opposites on their face, but shared a common flaw.

One example that comes to mind is the controversy around gun control. One side says 'gun sales and distribution should be controlled by the government' presumably to reduce the amount of guns, which would, in turn, reduce the amount of gun violence. The other side says the opposite, that 'gun ownership should not be controlled by the government because private ownership of guns is a Constitutional Right that needs to be protected' presumably so that ordinary citizens can protect themselves against the 'bad guys' wielding guns. While the two sides bicker endlessly over gun control/no gun control, nothing changes. Why? Because neither side cares to question why our society is so violent, on one hand. And, neither side cares to question what entities benefits financially by having such a violent society, on the other. With both sides avoiding these two critical questions, gun violence continues, fear continues, and the gun manufacturers keep selling guns. 
If Gramsci were alive today he would probably have seen the stated differences between Democrats and Republicans as superficial 'window dressing' since the big corporations and the wealthiest individuals continue to profit at everyone else's expense regardless of who is in power. And, it is ultimately that shared, unspoken hegemonic belief in the primacy of wealth that brought the Trump regime to power. Clearly, cultural hegemony is alive and well in the USA! What's more, the consequences of its triumph are already beginning to be felt. The dismantling of Obamacare and the massive tax cuts for the wealthiest individuals and corporations will lead inevitably to further subjugation and exploitation of middle classes and lower classes alike. It is as though the lower classes and the middle classes are being baited into fighting one another over crumbs while the wealthy surreptitiously empty both the larder and the safe.

\section{REFERENCES}

Banks, J.A. (1993). An introduction to multicultural education: Theory and practice. Boston: Allyn and Bacon/Pearson.

Bates, T. R. (1975). Gramsci and the theory of hegemony. Journal of the history of ideas, 36(2). pp. 351366. http://www.jstor.org/stable/2708933?seq=1\#page_scan_tab_contents

$B B C$ News. (January 30, 2010). Why do people vote against their own interests? Retrieved from http://news.bbc.co.uk/2/hi/americas/8474611.stm

Friere, P. (1970/2000). Pedagogy of the Oppressed. (M. B. Ramos, Trans.). New York: Bloomsbury. Gramsci, A. (1971/1999). Selections from the Prison Notebooks. Retrieved from https://goo.gl/xzVLs6 Kincheloe, J. (1993). Towards a critical politics of teacher thinking: Mapping the postmodern. New York: Praeger.

BENJAMIN H. WELSH, Ph.D. is an associate professor of higher education and urban educational leadership at Morgan State University. Dr. Welsh joined the faculty of Advanced Studies, Leadership, and Policy at Morgan State University in the spring of 2009. Prior to that, he served as assistant professor of educational foundations at Ball State University. Related positions that he has held include developmental English instructor at the Community College of Philadelphia, English teacher at Bartram High School in Philadelphia, and ACT Coordinator at the Philadelphia Job Corps Center. His dissertation focused on the research methods of the early educational researchers who were part of Stanford University's founding faculty circa 1890. What he uncovered was a eugenic ideology that appears to have been transmitted directly from the research methods into the fabric the American public-school system. Other teaching and research interests include white studies, multicultural education, the history of education, analytic philosophy of education, and the long-term impact of eugenics on our public schools. 